„Ante Portas - Studia nad Bezpieczeństwem”

2019, $\mathrm{Nr} 1(12)$

DOI: $10.33674 / 220191$

\author{
Vakhtang MAISAIA ${ }^{1}$ \\ Georgia \\ Koba KOBALADZE ${ }^{2}$ \\ Georgia
}

\title{
EURASIAN GEOPOLITICS IMPORTANCE TO WORLD POLITICS AND CHINA'S GEOSTRATEGY
}

\begin{abstract}
:
Since 1990 after bipolar system demolition and setting up new world order with liberal international order with American leadership endorsement lasted till 2014, the Eurasian space became one of the hottest spots in the world. Considering situational changes in the international security system with diminishing the global hegemony of the USA in case of confrontation with Russia and China, Eurasia has been increasing its geopolitical relevance to international politics. Several implications on endorsing new "Eurasian" alliances (Shanghai Cooperation Organization, Collective Security Treaty Organization, Eurasian Union, etc.) with primarily involvement of the countries of Post-Soviet space and China, directed against to NATO policy of enlargement could have created a rim of instability with "flexing mussels" between three nuclear powers - the USA, Russian Federation and People's Republic of China (PRC). Tripolarity agenda confirmed by the international security high-level expert community ${ }^{3}$, incoming world order is shaping up in the classical balance of power game of international relations ${ }^{4}$. Hence, the China-Russia alliance and strategic cooperation wrenched in the area really
\end{abstract}

\footnotetext{
${ }^{1}$ Vakhtang Maisaia, PhD, Professor, Head of the MA Program on International Relations and International Security Studies, Caucasus International University. Email: vakhtang.maisaia@ciu.edu.ge

${ }^{2}$ Koba Kobaladze, Major-General (retired), PhD student at Caucasus International University, Member of the Parliament of Georgia. Email: k070707k@ gmail.com

${ }^{3}$ Munich Security Report 2018, Munich Security Conference, Munich 2018, pp. 28-29.

${ }^{4}$ S. McGlinchey, R. Walters, C. Scheinpflug, International Relations Theory, Bristol 2017, p. 18.
} 
play an important role in fostering process at any level of the political spectrum: local, regional and certainly global.

\section{Keywords:}

CSTO, China, Russia, Eurasia, "Gazprom", National Security Concept, Military Strategy, NATO, Geostrategy, Geopolitics

\section{Introduction}

In a transition period of polarity main attention in the transformation of a nation's power entails composing strategic culture that makes it possible to promote the country's foreign policy goals at the global level ${ }^{5}$. Culture certainly plays a strong role in shaping strategic behaviour in China. There are two main strands of Chinese strategic culture today - the parabellum focused on realpolitik and the Confucian-Mencian strand, a philosophical orientation used mainly for idealized discourse ${ }^{6}$. The transatlantic-dominated world economic and political systems and the liberal world order underpinning it are currently undergoing a transformation so profound it equates to a Copernican revolution. However, after launching of China's "One Belt, One Road" strategic initiative with probably $\$ 400$ billion in value, a process of demolition of the liberal world order is quite reliable foreseen and Eurasian world order is forecasted in nearest future ${ }^{7}$.

China's military strategy is coined with the "One Belt, One Road" strategic objectives and relevantly is considered to provide military capabilities for the realization of the project. It is clear that China, by doing so, perceives transforming its status from regional into global actor status holders. The People's Republic of China is undoubtedly becoming an important player in international relations. The unprecedented economic growth China has experienced since the economic opening in 1978 led to the increased presence and importance of the country for regional and global development. Naturally, growing China is seen with suspicions from the existing powers, it is perceived as an important partner and a possible threat at the same time, especially by the United States. Understanding of Chinese intentions and perceptions of the reality of international relations and its own position is, therefore, crucial $^{8}$. In any way, due to China's geopolitical ambiguity the main goals of the

\footnotetext{
${ }^{5}$ C. S. Gray, War, Peace and International Relations: An Introduction to Strategic History, London-New York 2013, pp. 12-13.

${ }^{6}$ J. Baylis, J. J. Wirtz, C. S. Gray, Strategy in the Contemporary World, New York 2016, p. 92.

${ }^{7}$ P. W. Schulze, Multipolarity - The Promise of Disharmony, Frankfurt 2018, p. 211.

${ }^{8}$ R. Ondrejcsak, Introduction to Security Studies, Centre for European and North Atlantic Affairs (CENAA), Bratislava 2014, p. 123.
} 
military-strategic development of the national defence forces accord to socalled "Great Strategy" principles are the following:

- increase economic growth rates and raise the vital level of population to achieve a stable society;

- complete the modernization of the army;

- create potential for winning in any regional conflicts;

- become the centre of global influence - the strategy of economic hegemony;

- (BRICS, "Big Twenty", Shanghai Cooperation Organization, "one belt, one road" initiative).

There are key indications of how the national foreign and defence policy implications are promoting the national interests of the country and this is a very important case of other actors. It is interesting to underline that China's strategic military documents directly underlines the importance of countering other great power interest at the regional level. The Defence Strategy 2012 declares: "Over the long term, China's emergence as a regional power will have the potential to affect the U.S. economy and our security in a variety of ways"9. Therefore there are several options for the Chinese leadership in which ways have really achieved the mission with assistance of the allied powers, in case of the Russian Federation.

\section{China-Russia Gas Eurasian Deal Leads to New World Order}

It has already become a historical event Russia's President Vladimir Putin's official visit to Beijing on May 20th of 2014 and his meeting with his counter-partner Chinese President Xi Jinping. Later on, he attended Shanghai held a regional conference on Economic Development of the Asian-Pacific area. In this visit, Russia successfully tailored capabilities of two giant monopolies - "Gazprom" and "Rosneft". It is very interesting to note that "Gazprom" is ruled and owned by President Vladimir Putin and "Rosneft" is under the rulership of his "grey cardinal" Vice-Premier and Chairman of the Energy State Commission Igor Sechin and belonged to so-called "Siloviki" clan in political vertical of Russia ${ }^{10}$. Hence, the two leaders are seeking to pursue their own financial backup promotion and drastically changed and shifted the country's foreign policy priorities. In times of the official visit both Presidents have signed up to 40 agreements and contracts, including such strategic directions as are military-technical cooperation, energy politics

\footnotetext{
${ }^{9}$ The Diversified Employment of China's Armed Forces, 2013, <http://eng.mod.gov.cn/ Database/WhitePapers/index.htm> (30.06.2019).

${ }^{10}$ V. Maisaia, Contemporary Russia's Power Vertical: Clans Controlled by the Kremlin, [in:] New Eastern Europe-Eastern Partnership turns 10, No. 3-4, Cracow 2019, pp. 82-83.
} 
(for instance, Still, China remains Russia's most promising customer, with oil and gas consumption expected to increase by nearly 90\% in 2011-2020), agriculture, cooperation at international political levels with make congruent their foreign policy priorities (reaffirm both states positions at the UN Security Council and transform joint geopolitical project - Shanghai Cooperation Organization (SCO) as new type of politico-military coalition combating with US geopolitics at international and regional levels).

By fostering the strategic cooperation with Russia is in hands and national interest of China. This is indicated from the assumption that China's economic development is going on a critical level of transformation of political and military administration and management and is staying at a vital stage of promotion. At the time being, the Chinese GDP rate is composing of $87 \%$ of current US GDP figure but by 2020 the figure could be changed at an equal level. Hence, the official Beijing is in need of getting acquired toward vast and enormous natural resources of neighbouring Russia, mainly with energy resources, in order to further boosting national economic development. One of the key successful case-studies of the signed documents in aegis of Putin's visit to China is to be undermined - a signature of a memorandum of intention to create a common economic free zone in one of the regions Far East Region of the Russian Federation bordering with China. The joint mega-business project could be considered as a prerequisite toward the promotion of a more influential geopolitical mission - the creation of a native Eurasian Common Economic Union and Eurasian Common Custom Space. This is to be confirmed by the fact that Russia-China trade turnover reached up to $\$ 100$ billion per year. In this regard, it is to be mentioned that Russia and China were not reaching up a consensus on favourable prices for Russian gas delivery to China for at least 10 years and this was a hindering case to promote China-Russia relationship at all. China's Confucianism and Buddhism origin have increased its capabilities in geopolitical merits ${ }^{11}$. However due to great shifts in contemporary world politics - crises Ukraine and Syrian conflict where Russia and China have demonstrated common positions and expressed anti-Antlantist or anti-Western geopolitical visions. These positions are evidence for claiming from both sides to change unipolarity into multipolarity dimensions ${ }^{12}$.

From the Russian perspective, President Putin's "oriental geopolitics" overweight the failed Western trend was used to be at stake. The visit seems to be considered as very successful in that of mission achievement from the

\footnotetext{
${ }^{11}$ J. Haynes, An Introduction to International Relations and Religion, Edinburgh 2013, pp. 110-112.

${ }^{12}$ V. Maisaia, B. Oboladze, New Geopolitical Reality and International Terrorism in $21^{\text {st }}$ Century (Global and Regional aspects), Tbilisi 2009, pp. 11-12.
} 
Kremlin authority perspectives and only pure simply indications those concrete geopolitical achievements attained by the parties at global and regional levels:

1. Geoeconomic Partnership;

2. Global Financial Sabotage;

3. Geostrategic Partnership.

\section{Geoeconomic Partnership}

Russia reached a $\$ 400$ billion deal to supply natural gas to China through a new pipeline over 30 years, a milestone in relations between the world's largest energy producer and the biggest consumer. The gas delivery was to be starting in 2018 but the construction has delays. The amount of gas delivery is 38 billion cubic meters per year with an agreed price for $\$ 350$ per thousand cubic meters that is $\$ 30$ less than the price for the EU member-states customers. The deal is in hand for China too as Beijing pays for its gas supply from the Asian-Pacific area for $\$ 450$ per thousand cubic meters and fewer prices, about $\$ 280$ per thousand cubic meters, China pays to only Turkmenistan. The deal between Russia's state gas company, Gazprom, and China's state oil and gas company, CNPC, allows Russia to diversify its customer base, which is heavily dependent on sales to Europe. Moreover, China may make as much as \$25 billion in advance payments under the contract to invest in the necessary infrastructure. Russia will invest $\$ 55$ billion in the pipeline named "Siberian Strength" and the Siberian fields to feed it while China, responsible for a pipeline on its territory, will spend at least $\$ 20$ billion. Similar steps along with the "Gazprom" have been made by the Russian "Rosneft" taking its own part for promoting the Russian-Chinese strategic partnership - "Rosneft" will be delivered to China by 2020 around 46 million tons of oil and with direct involvement of the merger in Chinese city Tian-Zhen will be building oil processing factory.

Based on its resource assessment, the "Rosneft" expects to increase its oil production level up to $15 \%$ by 2020 due to the commitments arranged in China by the merger leadership. In conjunction with that trend, in the realization of the China-Russia energy project development could be involved the American merger "ExxonMobil" that makes ridiculous geopolitical disposition at global scope. As it is known, "Rosneft" signed up a contract with "ExxonMobil" in Sankt-Petersburg World Economic Forum (so-called "Russia Davos Forum") hold on May 22-25 of 2014 on further partnership in developing joint projects. One of the projects is directly linked with realization of the Russia-China joint geoeconomic partnership - "ExxonMobil" together with the "Gazprom" operates one of the Sakhalin fields with a $30 \%$ stake, partnering with companies from Japan (30\% stake), India (20\%) and two Russian companies 
(20\% combined - "Gazprom" and "Rosneftgas", a subsidiary company of the "Rosneft").

Subsidiaries of Gazprom, Netherlands-based Royal Dutch Shell, Japanese corporate group Mitsui and Japanese auto manufacturer Mitsubishi operate the other field. The project is expected to supply South Korea with 10 billion cubic meters of gas each year. It's expected to make China and North Korea into a sort of Ukraine, and it's expected to make South Korea akin to Europe with its present dependence on Russian gas. Russia has planned to build a gas pipeline and accompanying railroad from its offshore Sakhalin Island fields, north of Japan, through North Korea to South Korea. Moreover, "Rosneft" also expects to enlarge its activities beyond the Chinese, Japanese, North, and South Korean territories. "Rosneft" arranged a deal to deliver to Vietnam more than 6 million tons of oil and more expand its "oriental" direction. The other direction is India - "Rosneft" and the Indian ONGC energy merger has signed up a Memorandum of Understanding (MOU). Russia and India have been negotiating to build a $\$ 30$ billion oil pipeline, which would be the world's most expensive due to its proposed route through rugged terrain. The so-called Silk Road pipeline would link Russia's Altai Mountain region to the Xinjiang province of China and northern India. Russia exports $70 \%$ of its oil, compared to $30 \%$ of its gas production, and its oil revenues are nearly seven times its gas revenues. A bit yearly, Indian Prime Minister Manmohan Singh and Putin issued a joint statement from Moscow on Oct. 21, 2013, that confirmed that the two nations are collaborating "to study the possibility of direct ground transportation of hydrocarbons. In that respect and in aegis of the "oriental" geopolitics, the "Rosneft" with the Kremlin's direct influence, has arranged a geopolitical contract on the creation of a joint venture with Azerbaijan State Oil Company to extract and develop oil and gas fields in the Caspian Basin. By doing so, Russia seeks to monopolize the whole Eurasian energy resources under its control and deprive of West on diversifying its energy supplies options, including via Georgia transit routes. Russia-China geoeconomic alliance truly can subvert Western energy security and geopolitical stability.

\section{Global Financial Sabotage}

Russia and China have been reaching a consensus to impinge USA-EU financial "backbone". In Shanghai between two leaders of the countries have made a deal implying on neglecting the American dollar payment in trade transactions performed in aegis of the governmental agreements. The agreement was signed by the Russian bank VTB and the National Bank of China. The financial sabotage act is aimed to strike to the USA and EU against their sanctions imposed on Russia. In trade transactions and future types, financialeconomic deals will be using only Russian Rouble and Chinese Yuan as direct 
payment entities. In that stance, it is interesting why the contract was signed by VTB bank: "VTB Capital can expect to be informally crowned Russia's investment banking state champion by Prime Minister Vladimir Putin at its inaugural investor forum starting tomorrow in Moscow. It will be the first time the Russian leader has appeared at a brokerage event, underlining the rise of VTB Capital, which has become pivotal in managing the state's interests since its launch a little over a year ago. Its parent, VTB Bank, is $77 \%$ owned by the Russian Government"13.

Recently, China has suspended its transactions in American dollars with international commercial banks in Afghanistan and in South Asia. On its turn, Russia sold its own state bonds invested in the American state properties and in 2013 Russia sold $1 / 3$ of its bonds. The deal is a more dangerous weapon against West rather than relevant steps in energy geopolitics.

\section{Geostrategic Partnership}

Russia-China has reinforced its military-strategic partnerships. This fact was evidently demonstrated whilst Putin's visit to China. In Shanghai RussiaChina naval forces held a joint military drill in the Eastern-Chinese Sea named "Naval Interpartnership of 2014" with the participation of 8 Chinese Naval combat ships and 4 Russian ones with drones. The drills were commanded especially for that reason created joint Naval Command HQ. At the drills, the first time was demonstrated new Russian reconnaissance helicopter KA-28 at the Chinese Naval ships on board. Russia besides its novelty KA-28 has already handed over to China heavy fighters SU-27 and SU-30, transport jets IL-76, missile complex C-300 and some diesel submarines, class of "Varshiavanka".

In summary, China-Russia ties are boosted and aimed to swart to decrease of the dominance of the USA at the global political level. This factor is to be considered by the Georgian current leadership. All these elements and factors make China an important actor in the coming decades ${ }^{14}$.

\section{Russia-China Strategic Partnership - Stretching from Pacific Ocean till Black Sea Area}

The new Cold War scenario brings fresh realities in geopolitical distribution of power polarity in international politics. In conjunction with EU-

${ }^{13}$ VTB Capital: Putin's Favourable Bank? Bank Has Become The Kremlin's Adviser of Choice, "Financial News", 28.09.2009, <https://www.vtbcapital.com/events/2009/moscow/ news/681967/> (30.06.2019).

${ }^{14}$ J. S. Goldstein, J. C. Pevehouse, International Relations - 2013-2014 Update, New York 2014, p. 38. 
NATO-USA polarity configuration Russia-China strategic alliance seems more logical and real story. Apart from fencing down strategic partnerships in energy security, geoeconomic and security spheres, the Sino-Russia cooperation is deepening in the military sphere. Lately, two Chinese missile frigates have entered the Russian Black Sea naval base of Novorossiysk for the first time in history. They will then conduct joint exercises with Russia in the Mediterranean. The Linyi and the Weifang entered the port of Novorossiysk on May 8 to take part in Victory Day celebrations, according to the Russian Defence Ministry. Each is a 4,000-ton vessel of the relatively new Type 054A (also known as Jiangkai II), which first entered service in 2007. They are accompanied by a support ship. This is the first time Chinese warships will have entered the Russian base. The ships will then head to the Mediterranean for joint drills with Russian forces. "It is planned that the People's Liberation Army Navy warships will leave Novorossiysk on May 12 and relocate to the designated area of the Mediterranean Sea for the Russian-Chinese exercise Sea Cooperation-2015", the Russian Defence Ministry said in a statement before the drills taken place ${ }^{15}$.

The exercise took place from May 11-21 of 2015. Nine ships are scheduled to take part in total in the first drill of its kind to happen in the Mediterranean. The drills' goal has been stated as deepening friendly cooperation between China and Russia and strengthening their combat ability in repelling naval threats. The exercise comes at a time when NATO and its allies are holding a massive wave of military drills all across Europe. Collectively codenamed Operation Atlantic Resolve, NATO commanders and European leaders have said the training sends a message to Russia over its alleged aggression and the crisis in Ukraine. Some states are also conducting their own training manoeuvres parallel to Atlantic Resolve. Russia has been conducting a series of military exercises within its territory throughout winter and in early spring, including massive drills in the Baltic Sea, the Black Sea, the Arctic, and the Far East. The Chinese and Russian Navies have conducted exercises together since 2012 in waters off Russia's far eastern coast. Russia Deputy Defence Minister Mr. Antonov said there would be further Sino-Russian exercises in the Sea of Japan in August. Beijing's foray into the Mediterranean is seen as an attempt to extend its naval reach worldwide and emphasis a growing strategic partnership with Moscow against the West. A joint command centre for the exercises has been set up in Russia's Black Sea port of Novorossiysk, to which the Chinese vessels sailed before heading out with Russian ships for the Mediterranean. Russia's defence ministry said the drills were not targeted at a specific country but aimed "to

${ }^{15}$ Chinese warships to join Russian Navy in Black Sea, Mediterranean for historic drill, "Russia Today", 7 May 2015, <https://www.rt.com/news/256573-russia-china-novorossiysk-ships/> (30.06.2019). 
further deepen friendly and practical interaction between the two countries and strengthen joint efforts for countering naval security threats at sea". It is interesting to stress that demonstrative military "muscle" show in the Black Sea Basin was not accidentally fixed. Sometime before the drills, as Russia expresses its concern by increasing military presence in the Black Sea Region of the American and its ally NATO forces - just visiting of 600 American military instructors to Ukraine to train and equip the Ukrainian National Guard formation as well as holding in Georgia joint American-Georgian military exercises - about 600 U.S. and Georgian soldiers were taking part in the manoeuvres, for which the U.S. army for the first time transported an entire mechanized company, including 14 Bradley infantry fighting vehicles, across the Black Sea from Bulgaria. In addition to that, the NATO Alliance intends to deploy at a constant basis a brigade-size coalition military unit in Baltic Region in Lithuania in response to the reinforcement of the Russian military forces in Kaliningrad Oblast with the deployment of the tactical missile system "ISKANDER-M". Hence, Russia by doing joint military drills with China is seeking to demonstrate how the Kremlin could counter-balance military configuration in the Black Sea geostrategic gateway key location to get entrance to the Caucasus-Caspian Basin with widening the scope to the Central Asia where China holds its geostrategic interests ${ }^{16}$.

Moreover, China has been openly developing a naval strategy aimed at challenging American dominance of the western Pacific, including in the waters around Japan and Taiwan. China criticized an announcement last month by Barack Obama, the US president, and Shinzo Abe, Japan's prime minister, that the two countries were beefing up military cooperation. Hence, China with its military presence in the Black Sea close to Georgian seashore protects its own national interests to the western Pacific Rim to prevent American militarypolitical hegemony in the area. China-Russia is going to deepen its economic ties with considering the possibility to create a common trade and economic zone in and even a fragile opportunity to get China joined the Eurasian Economic Union and create a common Eurasian Grand Coalition with security, energy, economic and military components of strategic cooperation ${ }^{17}$. It was not surprising an initiative stemming from the Turkish Foreign Affairs Minister Mevlut Chavushouglu reflected at Anatolia NATO Foreign Affairs Minister session to launch so-called "access talk" procedures with four NATO member candidates: Macedonia, Bosnia and Herzegovina, Montenegro and Georgia. A new geopolitical muscle race is ahead and where Georgia is to be placed in another case of debates.

\footnotetext{
${ }^{16}$ E. Gvenetadze, Aspects of International Security, (in Georgian) Tbilisi 2017, pp. 67-68.

${ }^{17}$ J. Gakhokhidze, Main Problems of International Security, Tbilisi 2017, pp. 56-58.
} 


\section{Russia, Iran and China Create anti-NATO Alliance: What's for?}

Iran and Russia have launched to promote a new trend of military cooperation. The Iranian Defense Minister Hossein Dekhan, Brigadier General, has come out with a proposal to create more close military cooperation and strategic partnership among Iran, Russia, India, and China to prevent and cope with the NATO enlargement policy to East and with deployment U.S. Missile Defence Program elements in the Mediterranean and Black Sea Areas. He made the statement at the Fourth International Conference on Security Issues hold in Moscow on April 15-18 of 2015. The initiative was in conjunction with Russia's Defence Minister Sergey Shoigus's adherence to set up a distinct military alliance to stop NATO further enlargement. Sometimes before three countries with similar political authority provisions and structures - Iran, Syria, and Russia have exposed to increase politico-military strategic partnerships to cope with common challenges and threats. Having considered the fact that Russia is pending on further reinforcement of the military ties with its allies in aegis of the Collective Security Treaty Organization (CSTO) with involvement of the seven post-Soviet states: Russia, Armenia, Belarus, Kazakhstan, Kyrgyzstan, Tajikistan and Uzbekistan, mainly in way of creation of Rapid Reaction Forces and Anti-Air Defence Common System with incursion of Anti-Missile Defence elements, it becomes clear why Russia is seeking to create so-called "second rim" of collective defence system in Eurasian geopolitical space ${ }^{18}$.

By doing so, the Russian authority will set up a counter-balance condition to counter-weight successfully the NATO engagement into the Black SeaCaucasus-Caspian regional entity. Moreover, Russia is promoting its strategy to bilaterally reinforce its linkage with China and India, including in the military field of cooperation. Russo-China's strategic cooperation is being stipulated in aegis of the Shanghai Cooperation Organization (SCO) as a "third rim" of the collective defence system enlarged Eurasian Global Security postures. In the aegis of the SCO is possible of joint cooperation in combating terrorism with military means and promoting regional security principles among the countries, like China, Russia, Iran, and India. The three-tier system of collective defence will be a new modality to counter-weight EU-USA hegemony at the global level ${ }^{19}$.

The first "tier" of the collective defence includes very close cooperation in the military sphere of Russia with de-facto republics of Abkhazia and South

\footnotetext{
${ }^{18}$ W. N. Konyszew, A. A. Siergunin, Sowriemiennaja wojennaja stratiegija, Moscow 2014, pp. 85-86.

${ }^{19}$ G. Magradze, V. Maisaia, $21^{\text {st }}$ Century International Politics and "Cooperation Security" Theory: Myth and Reality - Regional and Global Levels, Tbilisi 2017, pp. 118-120.
} 
Ossetia arranged with proper agreements at so-called "inter-state" conditions and more reinforce the Russian military presence in the Black Sea-Caucasus area. According to the Russian experts and specialists of international politics, for instance, Dr. Andrei Sushentsov and Dr. Andrei Bezrukov, who claim that international organizations do not reflect the real balance of power, and entering with West in new Cold War conditions Russia has attained several positive geostrategic missions, never ever before achieved before ${ }^{20}$. The positive missions could be defined in the following manner:

- Russia has managed its dominance and reached hegemony at the Black Sea basin and pursuing national interests in the area forgetting about ethical and moral principles of international relations origins. Russia has openly demonstrated its true Realpolitik in action and repulsed the USA attempts to contain Russia as in the case of the Soviet Union in geopolitical borderlines of the Eurasian "Heartland". As it clears geography has shaped Russian identity and its rulers understanding of security throughout the entire existence of the Russia's statehood ${ }^{21}$;

- Russia seized and captured a very strategic place in the Black Sea area Sevastopol port without a frozen duration period of time and with the possibility to really increase Black Sea Naval Fleet capabilities and deploy Strategic Command HQ of the Fleet in Crimea. With forging an agreement with de-facto Abkhazia, Russia has more increased its geostrategic presence in the area;

- Russia has gained more than 2 million Russian-speaking populations full loyalty of the Crimean peninsula and from the expert's expectation ended its "historic mission" of regaining control over the originally "Russian" territory. The provision is very alike to Nazi Germany Anschluss of Austria and Sudetes District of Czechoslovakia in 1938;

- Russia managed to avoid full international isolation from the Western community and reached of creation of the strategic partnership arrangements with some other Global Power Centres - India and China.

These are only perceptions dominated at contemporary Russia's political analyst and expert community circles and these assumptions could have some grounds, possible ones perhaps amid who knows how real or true are they. In addition to Iran's Defence Minister's proposal on the creation of the antiWestern military alliance, it should be considering that China, India, Iran, and

\footnotetext{
${ }^{20}$ A. Radin, C. Rich, Russian Views of the International Order, RAND Corporation, Santa Monica 2017, pp. 34-35.

${ }^{21}$ J. Gurganus, E. Rumer, Russia's Global Ambitions Perspectives, Carnegie Endowment for International Peace, <https://carnegieendowment.org/2019/02/20/russia-s-globalambitions-in-perspective-pub-78067> (30.06.2019).
} 
Russia with the possible incursion of Syria could be pursuing some concrete geopolitical implications as are:

- suppression of NATO's enlargement to the Caucasus and Central Asia direction and halt its domination at the Black Sea basin;

- coping with the common military asymmetric threat in the face of Islamic Caliphate threaten to all engaged parties personally;

- stopping deployment of U.S. National Missile Defence Program elements at the Black Sea area;

- dealing with the situation in Afghanistan mostly after the post-ISAF period of time and preventing of "Taliban" back to power in Kabul that makes great troubles to the countries supposed to be a member of the alliance;

- providing full-pledge support to Syrian ruling Assad authoritarian regime and reinforcing of Russo-Iran presence in the Middle East region;

- promoting probable alliance member-state national military industry complexes cooperation and fostering joint armament project development.

This hypothetical scenario is very easily transforming into the reality that makes possible to shift present world order in a proper manner. "Eurasian Alliance" could be a signal on the reorientation of international society priorities from the Western direction toward Eastern one ${ }^{22}$.

\section{Conclusion}

In retrospect to contemporary world order being still in transition is becoming an uprising topic of what kind of new global actors emerged. The USA declining in the global hegemony mission that made it possible for coalition two Eurasian powers - China and Russia at least in spheres of energy security, defence policy, and foreign policy cooperation. Having considered the development of multipolarity system arrangements in aegis of international politics several times increases the role of the regional geopolitics ${ }^{23}$. China's new military geopolitics implicates the transformation of regional power hegemony status into global hegemony one. Therefore new Eurasian world order pattern requires the creation of new military alliance as well as economic and political unions for fostering the order in the proper final end. China and Russia rapprochement in spheres of military strategic cooperation, energy security, political solidarity, foreign policy task coordination and environmental security has demonstrated how far the process of the "Eurasian Alliance" could

\footnotetext{
${ }^{22}$ P. W. Schulze, op. cit., p. 110.

${ }^{23}$ See: N. Chitadze, Politology, Tbilisi 2016, pp. 432.
} 
be promoted and reached their successful story end. Moreover, Russia and China have been modifying their efforts to promote their national interests in such geostrategic important regions as are: the Caucasus-Caspian region, Black Sea Area, Middle East and Persian Gulf and what is curious the Central and South American regions (Cuba, Venezuela, Nicaragua, Ecuador, Bolivia, etc.) where accord to Monroe Doctrine of 1823 rests the USA vital national interests and the area is considered as the most domain influence of the White House in Washington D.C. Even more, Russia, China, and Brazil are the members of the global "South" domain organization - BRICS count-balancing the USA global hegemony or at least to have to try to. The "Eurasian Alliance" could be supplemented by the other actor of the geopolitical space - the Islamic Republic of Iran whose geopolitical ambitions are very high and promoting its nuclear project despite severe economic sanctions imposed by the Trump Administration at the time being, means to fulfil the mission. By doing so, Russia cast itself as the bastion of global protection against "aggressive" West and a hegemonic America ${ }^{24}$. The combination of the powers: China with Iran and Russia indeed manage to outweigh the American hegemony ambiguities not only at regional but also at global levels and re-shaping liberal international order modality. As it is known, Brzezinski's Eurasian Balkans concept is the apex of American geopolitical thinking ${ }^{25}$ and by doing so, the USA interests only flatter enough to consider the area from new type asymmetric challenges dealing agenda and is less attentive to cast its global geopolitical missions. However, the configuration and projections of "three power" capabilities into common unity, several times increase the role of the Eurasian space in geopolitical games and stipulate pushing ahead of new world order provisions.

\section{BIBLIOGRAPHY:}

$\checkmark$ Baylis J., Wirtz J. J., Gray C. S., Strategy in the Contemporary World, New York 2016

$\checkmark$ Bugajski J., Assenova M., Eurasian Disunion: Russia's Vulnerable Flanks, Jamestown Foundation, Washington 2016

$\checkmark$ Chitadze N., Politology, Tbilisi 2016

$\checkmark$ Gakhokhidze J., Main Problems of International Security, Tbilisi 2017

\footnotetext{
${ }^{24}$ J. Bugajski, M. Assenova, Eurasian Disunion: Russia's Vulnerable Flanks, Jamestown Foundation, Washington 2016, p. 20.

${ }^{25}$ A. Korybko, Hybrid Wars: The Indirect Adaptive Approach to Regime Change, Moscow 2015, p. 17.
} 
$\checkmark$ Goldstein J. S., Pevehouse J. C., International Relations - 2013-2014 Update, New York 2014

$\checkmark$ Gray C. S., War, Peace and International Relations: An Introduction to Strategic History, London-New York 2013

$\checkmark$ Gurganus J., Rumer E., Russia's Global Ambitions Perspectives, Carnegie Endowment for International Peace, $<$ https://carnegieendowment.org/2019/02/20/russia-s-global-ambitionsin-perspective-pub-78067>

$\checkmark$ Gvenetadze E., Aspects of International Security (in Georgian), Tbilisi 2017

$\checkmark$ Haynes J., An Introduction to International Relations and Religion, Edinburgh 2013

$\checkmark$ Konyszew W. N., Siergunin A. A., Sowriemiennaja wojennaja stratiegija, Moscow 2014

$\checkmark$ Korybko A., Hybrid Wars: The Indirect Adaptive Approach to Regime Change, Moscow 2015

$\checkmark$ Magradze G., Maisaia V., $21^{\text {st }}$ Century International Politics and "Cooperation Security" Theory: Myth and Reality - Regional and Global Levels, Tbilisi 2017

$\checkmark$ Maisaia V., Contemporary Russia's Power Vertical: Clans Controlled by the Kremlin, [in:] New Eastern Europe-Eastern Partnership turns 10, No. 3-4, Cracow 2019

$\checkmark$ Maisaia V., Oboladze B., New Geopolitical Reality and International Terrorism in $21^{\text {st }}$ Century (Global and Regional aspects), Tbilisi 2009

$\checkmark$ McGlinchey S., Walters R., Scheinpflug C., International Relations Theory, Bristol 2017

$\checkmark$ Munich Security Report 2018, Munich Security Conference, Munich 2018

$\checkmark$ Ondrejcsak R., Introduction to Security Studies, Centre for European and North Atlantic Affairs (CENAA), Bratislava 2014

$\checkmark$ Radin A., Rich C., Russian Views of the International Order, RAND Corporation, Santa Monica 2017

$\checkmark$ Schulze P. W., Multipolarity - The Promise of Disharmony, Frankfurt 2018

$\checkmark$ The Diversified Employment of China's Armed Forces, 2013, <http://eng.mod.gov.cn/Database/WhitePapers/index.htm>

$\checkmark$ VTB Capital: Putin's Favourable Bank? Bank Has Become The Kremlin's Adviser of Choice, "Financial News", 28.09.2009, <https://www.vtbcapital.com/events/2009/moscow/news/681967/> 